\title{
Surgical History
}

\section{Charles B.G. de Nancrede: Academic Surgeon at the Fin de Siècle}

\author{
David A. Bloom, M.D., Gretchen Uznis, B.A., Darrell A. Campbell, Jr., M.D. \\ Department of Surgery, University of Michigan, 1500 East Medical Center Drive, Ann Arbor, Michigan 48109-0330, USA
}

\begin{abstract}
At the last turn of the century American surgery was in the midst of a number of paradigm shifts, involving transitions in technology, surgical practice, surgical specialization, patient care, surgical training, and medical economics. Charles B. G. de Nancrede was a leader during this formative period. A key figure in the transition from antiseptic to sterile technique in American medicine, he was also a prolific writer, a bold surgeon, and a great surgical educator. De Nancrede created one of the earliest prototypes of the modern multispecialty surgical departments. The coming turn of the century promises new transitions comparable to those of the past.
\end{abstract}

Approaching the year 2000, one recalls the last fin de siècle with its unparalleled intellectual ferment and productivity. Great figures such as Thomas Edison, Sigmund Freud, and Arnold Schoenberg created revolutionary concepts and innovations that have illuminated our entire century. The initial characterization of the fin de siècle as a period of decadence was no doubt a reaction of conventional wisdom to the shock of the paradigm shifts.

At the same time surgery, and indeed all of medicine, were in the midst of tremendous changes, which were clearly reflected in the career of Charles B. G. de Nancrede (Fig. 1). This surgeon and educator was quick to recognize and incorporate the new concepts. He not only bridged the fin de siècle but also paralleled an era described as la belle époque. This period of 1871-1914, between the Franco-Prussian war and World War I, was characterized by relative peace in Europe and by marked advances in technology and the arts. La belle époque was an especially fertile and formative time for the profession of surgery.

Paradigm shifts, which were transforming nearly every aspect of surgical practice and education, involved sterile techniques, specialization, operative procedures, surgical training, new technologies, the use of the hospital, and patient care. The battle of listerism was in its final stages, and the transition from antiseptic to sterile technique was under way. Surgical subspecialization was emerging, and anesthesiology was demarcating as a distinct profession. Professional societies formed along specialty lines, with active readerships in new journals and books. Innovative operative procedures were applied in abdominal, gynecologic, intracranial, orthopedic, plastic/reconstructive, and urologic surgery. Surgical training shifted from apprenticeships and the sheer terror of bedside learning to structured residency programs.

Correspondence to: D.A. Bloom, M.D.
Newer technologies such as radiography, endoscopy, chemical analysis, and microbiologic techniques altered methods of diagnosis and treatment. Furthermore, the hospital was becoming the center of patient care, where specialists and the new technologies converged. The profession of nursing was elevating the standard of patient care.

\section{Roots, Education, and Philadelphia Years of de Nancrede}

Charles Beylard Guerard de Nancrede's grandfather, Paul Joseph de Nancrede, first came to the Colonies as a lieutenant in the French Army. Wounded at Yorktown, he stayed in America and became a naturalized citizen in Boston in 1801, when he dropped the "de" prefix of his name. For a time he was a professor of French at Harvard University, but in 1804 he returned to France with his wife Hannah Dixie to ensure a French education for their eight children. After 8 years the family sailed back to America in 1812 and settled in Philadelphia. Two sons, Joseph and Nicholas, became successful physicians. Another son, Thomas Dixie Nancrede, developed a large wholesale importing business. Thomas Dixie Nancrede and his wife Mary Elizabeth Bull had four children of whom Charles Beylard Guerard was the third. He was born in Philadelphia in 1844.

Charles was educated in private classical schools and a military academy. His intense desire for a military career was opposed by his father after the death of an uncle in the war with Mexico [1]. Charles received an M.D. degree from the University of Pennsylvania in 1869. Completing an internship at Episcopal Hospital in Philadelphia, he began a general practice of medicine. His interest and talents focused on general surgery, and he developed a vigorous career. Charles remained on the staff at Episcopal Hospital, eventually becoming its attending surgeon [1]. He performed orthopedic, urologic, vascular, neurologic, and ophthalmic surgery. His wide range of publications between 1870 and 1890 reflected this versatility [2].

In 1872 Charles married Alice Dunnington of Baltimore, who eventually gave birth to nine children. The original family name, de Nancrede, was subsequently restored by Charles around 1905 $[1,3]$.

De Nancrede's surgical skill was widely praised in Philadelphia where he taught short courses to other practitioners. He was the first in that city to operate for bullet wounds of the stomach and intestines [1]. Surgical management of missile injuries to the 


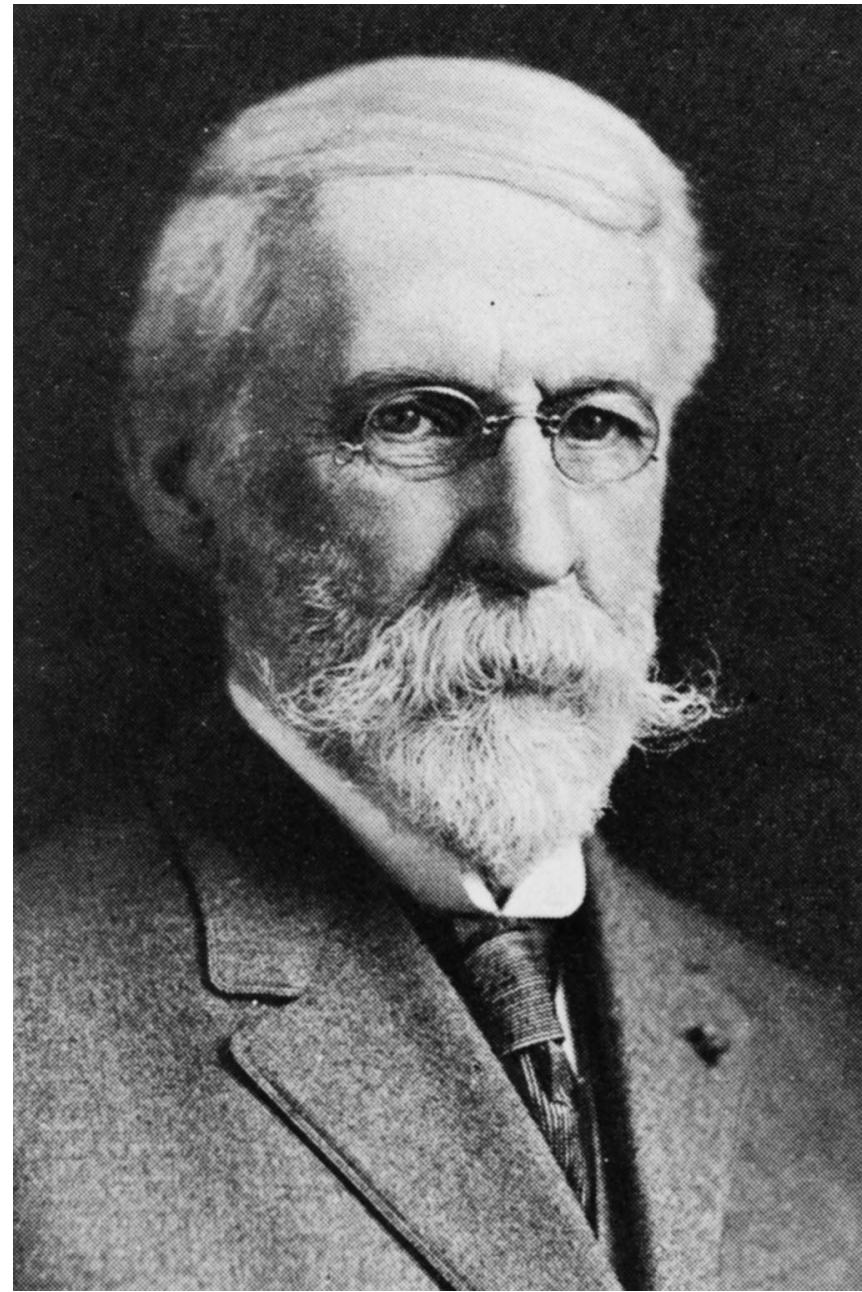

Fig. 1. Professor de Nancrede in Ann Arbor.

viscera became one of his primary claims to fame. His papers analyzed the physics of projectiles and their effects on tissue, with concern for asepsis never far behind. In one paper he wrote, "As has already been demonstrated, the 'explosive effects' of modern balls at the distance of which most must strike in an actual engagement, will not produce such destruction of bone as often to demand amputation, if asepsis can be secured" [4]. Appendicitis, a clinical entity first described in 1886, remained a topic of great interest to de Nancrede throughout his career. He was one of the first to operate for appendicitis, and he later reported left-sided appendicitis in a 5-year-old boy without situs inversus [5].

De Nancrede grew to be a leader in surgical education. He was an anatomy instructor at his alma mater. His textbook Essentials of Anatomy and Manual for Practical Dissection was first published in 1888 and lasted for 7 editions [6]. The first edition contained 119 black and white illustrations, but by 1890 the third edition had 30 color lithographs and 180 black and white illustrations. Davenport noted that the same colored plates were reprinted 30 years later in Keen and White's surgical textbook [2]. De Nancrede served as an attending surgeon and clinical lecturer on rectal and general surgery at Jefferson Medical College as one of the understudies to the legendary Samuel Gross. In 1882 de Nancrede was elected to the American Surgical Association, which was meeting in Philadelphia, with Gross as President. Jefferson Medical College awarded de Nancrede his second M.D. degree in 1883. This was a regular graduate degree, not an honorary one, and seems to have been the result of attendance at a course of lectures during the 1882-1983 session and submission of a thesis entitled "Jaborandi" (D. Flanagan, Thomas Jefferson University, 1996, personal communication). The title refers to the "dried leaflets of a Brazilian plant Pilocarpus pinnatifolius having diuretic and sudorific properties" [7]. No remains of the thesis itself has been located. De Nancrede was an attending surgeon at St. Christopher's Hospital for Crippled Children and for a time was the clinical chief of the eye and ear service at the University of Pennsylvania. He became emeritus professor of general and orthopedic surgery at the Philadelphia Polyclinic.

In 1896 Watson's biographical sketches of physicians and surgeons in America included this comment on de Nancrede: "He was one of the very earliest, if not the earliest, to adopt strict Listerism, and fight its battles in America" [8]. Advocacy of these antiseptic methods placed de Nancrede at odds with Samuel Gross, who was a firm contrarian regarding listerism [2]. Colleagues later wrote that de Nancrede, Keen, and Mears were "given the credit of establishing the principles of antiseptic surgery in the United States. Doctor de Nancrede followed the methods of Lister through the 'carbolic acid spray' period to the full development of antiseptic surgery during the nineties" [1] Lister's basic tenet was that antiseptic techniques prevented infection. Whether the techniques involved carbolic acid spray or other materials and methods was of far less importance than the antiseptic philosophy itself. The sterile instruments and gloves that followed at the fin de siècle were evidence of a paradigm shift from antiseptic to aseptic technique. Antisepsis focused on the neutralization of germs in vulnerable areas, whereas asepsis implied a germ-free (sterile) field. The new century neatly divided these two concepts. The aseptic paradigm was higher on the technology food chain, requiring sterilization methods, gowns, gloves, and other supplies.

\section{Ann Arbor Years}

In 1889 de Nancrede was recruited to the University of Michigan as Chair of Surgery by its renown dean, Victor Vaughan. Ann Arbor's rustic Pavilion Hospital, the first hospital in the United States owned and operated by a university, had been built in 1877 . It accommodated 150 patients and had an operating amphitheater, but for de Nancrede it was a far cry from the modern Philadelphia clinics: "He came from one of the best equipped hospitals of the East to a primitive wooden barracks scarcely deserving the name of hospital, without instruments, without nurses. For many years he furnished his own instruments" [1].

Yet de Nancrede flourished in Ann Arbor, and the department of surgery prospered under him. Quickly becoming an influential figure at the University of Michigan, de Nancrede presided over the completion of the West Hospital in 1892. This facility served new purposes compared to the old Pavilion Hospital. Howell, a perceptive analyst of medical technology and its evolution, wrote: "Between 1890 and around 1925 the U. S. hospital underwent a dramatic transformation. Initially nineteenth-century repositories for the dependent poor, by some time after the end of World War I hospitals had become self-consciously scientific institutions" [9] 
In the university's West Hospital de Nancrede established an efficient surgical department known for excellent patient care and effective training of students. In contrast to his predecessors, he practiced exclusively in the university hospital and had no private office. Cyrenus G. Darling served as his assistant and eventually became his successor. Owing to his work at Ann Arbor, de Nancrede's national reputation continued to grow, and in 1890 he was elected vice president of the American Surgical Association when it met in Washington, DC at the Army Medical Museum.

After Essentials of Anatomy, his only other book was Lectures on the Principles of Surgery, which was published in 1889 and 1905. De Nancrede used this material to teach medical students [10]. The text was organized into 36 lectures that focused on the specific principles rather than the skills of surgery. Experience and opinion were sometimes admixed with experiments. The first three lectures discussed hyperemia. Regarding inflammation, de Nancrede noted its origination from predisposing causes and germs, additionally commenting that "other low forms of vegetable life which are not microbes induce pathogenic processes in man, as the ray fungi, the actinomycetes" [10]. The classic hallmarks of disease were recounted (rubor, calor, tumor, dolor, and functio laesa) [10]. De Nancrede believed that inflammation and infection were one and the same thing, and he adhered to this notion throughout his clinical life.

In Lectures on the Principles of Surgery, de Nancrede described a diversity of topics including precise clinimetric observations (e.g., red blood cell counts), fat embolism, drug toxicity, tetanus, hydrophobia, cautery devices, sterilization methods, shock, and local and general anesthesia. He presented the University of Michigan formula for local anesthetics in the 1905 edition, commenting [10]:

It will be seen from the strength of the formulas employed that it is hardly possible that a dangerous amount of coccain can be absorbed:

occain hydrochloride gr. j

morphine sulfate gr. $1 / 9$

acid carbol. gr. j

sodium chloride gr. $\mathrm{j}$

aqua $3 \mathrm{j}$

The 1905 second edition of Lectures on the Principles of Surgery was not substantially different from the first edition. For example, the single reference to bloodletting by leeches was on the same page (page 119): "Diminution of the contents of the veins may be effected by means of leeches or wet-cups always remembering that to be useful the blood must be drawn from the vein" [10].

De Nancrede spent part of 1898 as a surgeon and major in the U.S. Army during the Spanish-American War and was wounded in Cuba. His long-standing interest in missile injury dovetailed with a patriotic sense of military duty that stemmed from the family roots and his childhood inclinations. As World War I was about to unfold years later, he sought active service in the Army (at age 70!) but was permitted to participate only in the ROTC (Reserve Officers Training Corps). This disappointed him greatly [1].

The surgical department that de Nancrede took over in 1899 in Ann Arbor had been in turmoil regarding the site of clinical instruction. Donald Maclean, the previous professor of surgery, had lived and practiced in Detroit, where he believed the clinical focus should remain. Dean Vaughan had this to say on the matter: "I never believed in the removal of the Medical School, or even its clinical teaching, to Detroit. It was on this rock that I broke with two of the best friends I ever had, Frothingham and Maclean" [11]. (George E. Frothingham was the first professor of ophthalmology.) Maclean resigned bitterly in 1889 at the suggestion of the Regents. As in most medical schools at the time, surgical teaching largely took a back seat to private practice, and there was virtually no subspecialization within surgical departments.

De Nancrede had a different vision. He maintained his entire practice at the university hospital and, in time, turned over many facets of his broad general surgical practice to new specialists he enlisted for his growing department. Gynecology was assigned to Martin (1892) and later to Peterson, oral surgery to Darling, and genitourinary surgery to Loree (1906); and in 1911 Allen Richardson became the first full-time anesthesiologist. De Nancrede's official title changed in 1904 to Professor of Surgery and Director of the Surgical Clinics at Michigan. By this time Ann Arbor indeed had a recognizable academic surgical unit.

The professor invested time in his students and was an earnest surgical educator. Victor Vaughan considered de Nancrede somewhat of an icon.

I can not overestimate the service rendered to the University by this man His presence was an inspiration; his diagnostic skill in both surgical and other conditions was unsurpassed; his devotion to his patients has been seldom equaled; many a midnight hour, without much regard to weather, found him in the hospital; skillfully unremittingly, without thought of self, devoting all his energy to the care of his patients [11].

In a conference on classical education in 1906 in Ann Arbor, de Nancrede commented on Victor Vaughan's paper on the value of humanistic studies in preparation for the study of medicine. De Nancrede vigorously defended a foundation in Latin and Greek: "[L]ack of knowledge of the dead languages proves a serious interference to teaching medicine" [12].

De Nancrede was elected President of the American Surgical Association in 1909 when it met back in Philadelphia at the Bellevue-Stratford Hotel. From 1900 to 1913 de Nancrede additionally held the position of Professor of Surgery and Clinical Surgery at Dartmouth Medical College, becoming Emeritus Professor in 1913. The duties in this New Hampshire appointment were satisfied during the lengthy summer vacations permitted during that era. De Nancrede became emeritus professor at Michigan in 1917. His last photograph with the graduating class of 1918 reveals 20 faculty members and 66 students. The class was a diverse one, with Asian, black, and female faces.

De Nancrede passed away only 3 years later. The University of Michigan's Encyclopedic Survey reported: "He died in Detroit in 1921, leaving, as do most physicians, little tangible evidence of the great service he had rendered to humanity" [3]. The memorial written by Warthin and colleagues [1] in 1921 concluded with this comment:

Through the thousands of patients passing through his hands in the surgical clinic of the University Hospital, through the many rescued by his skill and care from painful disease or impending death, he has given to the University a rich legacy of debt and gratitude from citizens in nearly every city and village in the state. In the deeper appreciation of the University by the state may we not find some returns of the harvest from the seeds sown by Doctor de Nancrede? It is often said that the State University, as an institution, is cold-blooded and ungrateful, using the lives and energies of its servants; then after these have been drained of their usefulness in its service, tossing them aside with indifference, neglected or forgotten. If this be true, the fault is our own; it rests upon us, the servants of the institution. Rather be ours the sacred duty to keep alive the memory of those who 
gave their all to its service, and at their departure to render them fitting honor.

\section{De Nancrede in Perspective}

De Nancrede was one of the most prominent surgeons and surgical educators of his era. He contributed to nearly all surgical texts of the time, and his publications covered most facets of surgical practice. Watson described him as a voluminous writer of papers [8]. His laboratory interests were similarly wide-ranging, encompassing canine gastric fluids, effects of phlebotomy on inflammation, sterilization of catheters, missile injuries, and catgut absorption. In addition to being one of the first surgeons to operate on gunshot wounds of the intestines, he was one of the earliest to operate for brain abscess and to excise cortical centers for epilepsy [13].

Straddling the nineteenth and twentieth centuries in the midst of la belle époque, de Nancrede practiced, taught, and advocated listerism and sterile technique (as evidenced by papers on the antibacillary treatment of tubercular joint disease [14]) and boiling as a method of sterilizing catheters [15]. He discussed sterilization of ligature materials in a paper entitled "A preliminary note on the sterilization and absorbability of catgut" [16].

De Nancrede carried his firm belief in listerism from Philadelphia to Ann Arbor and was one of the pivotal leaders in the use of sterile technique. The medical library at the University of Michigan still contains a book he donated on that subject, bearing a bookplate with his signature (Fig. 2) [17]. Photographs of de Nancrede operating in Ann Arbor with bare hands in 1890 but gowned and gloved in 1910 show the antiseptic-to-aseptic paradigm shift (Fig. 3). The concepts of sterile technique had taken nearly a century to unfurl, although one could argue that recognition of the importance of cleanliness during invasive procedures was present nearly a millennium past in the works of Avicenna [18]. Certainly the observations of Holmes (1843), Semmelweiss (1847), Lister (1865), Pasteur (1875), and Koch (1878) were well known in la belle époque, although the surgical mainstream was slow to change direction. As late as 1898 aseptic concepts were still newsworthy for some of de Nancrede's contemporaries, such as McBurney [19] who wrote:

During the last few years the conviction has constantly become deeper and more widely spread among surgeons that the important agents of wound infections are to be sought for among the palpable objects which come in direct contact with the wound ... that part of the patient which is to be surgically operated upon shall be surgically clean, and that every object which is to come into contact with the wound or its immediate neighborhood, whether it be hand, instrument, sponge, ligature or dressing, shall be as sterile as possible. Not only do we insist that these objects shall be sterile at the beginning of our operation, but we make every effort to keep them sterile until its finish.... No matter what improvements in surgical technique may be in the future, it is certain that they will always be in the direction of obtaining and preserving more perfect asepsis in the direct handling of the tissues in a wound.

McBurney further noted that his friend Dr. Halsted (a pivotal figure in the introduction of rubber gloves) since 1891 had insisted that his assistants wear gloves during surgery, initially to protect their hands from the corrosive antiseptics. In time, however, Halsted came to recognize the aseptic value of gloves. By 1898 McBurney said this of Halsted and his gloves: "He has a high opinion of their value as a measure of avoiding wound infection" [19].
De Nancrede was a prototype of the modern surgical educator, creating a vigorous academic surgical unit in Ann Arbor, lecturing to students and house officers from his textbooks, and performing laboratory research to answer questions raised by daily surgical practice. He was effective in the medical school and university administration, which were politicized then no less than they are today. Scarce resources were garnered and shaped toward his needs and aspirations for the department of surgery. That no specific operative procedure, device, or mnemonic retained his name in our contemporary lexicon does not diminish the importance and influence of de Nancrede as an academic surgeon. The issues that confronted him 100 years ago have contemporary parallels for academic surgeons at our impending turn of the century.

\section{Fin de Siècle: de Nancrede's and Ours}

As one century ends and another begins pundits are compelled to retrospection and forecast. The key issues in academic medicine for de Nancrede at the last fin de siècle related to economics, education, surgical practice, and technology.

The economics of medicine were no less contentious then than now. The 1890s saw the beginning of health insurance. Uncompensated care and clinical medical education were largely funded by resources from private medical practice. According to a 1907 survey, physicians' incomes had been flat for several decades as Martensen [20] described:

Fee-for-service individual practices were not holding their own against what was known as "contract medicine." The United States was becoming a nation of organized economic units, some of them large industrial and financial enterprises, and these groups used their buying power to bid down physicians' fees. For example, Aetna Life and Accident Company provided some employers with group health policies at an employee rate of $\$ 1.00$ per month, but participating physicians received only $10 \%$ of that Competition from health insurance companies and the mutual aid societies caused many physicians to experience a shrinking of their core practices (i.e., the skilled-trade and middle-class populations).

These comments have a familiar ring today. Specific differences in contemporary medical economics relate to a more pervasive involvement of third-party payers. In addition, the new phenomenon of the corporate medical megabusiness and managed care that has virtually exploded during the past few years will most likely dominate the health care environment in the United States in the near future, perhaps creating an environment favorable for a national health care alternative.

Medical education in de Nancrede's time was offered in a variety of settings, without a governing authority or national standard. The University of Pennsylvania and Jefferson Medical College were high points of the national educational scene, whereas Ann Arbor was a rural outpost on the rise. Flexner's report in 1910 provided the first major survey of medical education and conveyed an implied set of values [21]. Critical issues for the next fin de siècle include medical education financing (the rising student indebtedness and the diminishing clinical revenues that fund much of the educational budget), maintenance of educational and scholarly values in a world of corporate medicine, and the appropriate balance between generalist and specialist training.

Surgical practice at the start of de Nancrede's professional life was barely specialized (his focus on surgical practice was unusual and largely self-taught). Science, as evidenced by listerism, was at 


\section{ANTISEPTIC SURGERY.}

THE PRINCIPLES, MODES OF APPLICATION, AND RESULTS OF

\section{THE LISTER DRESSING.}

B Y

DR. JUST LUCAS-CHAMPIONNIÈRE, SURGEON TO THE HOPITAL TENON, MWMHER OF THE SOCIETE DE CHIRURGIE,

EDITOR OF THE JOURNAL DE MÉDICINE ET DE CHIRURGIE PRATIQUES.

TRANSLATED FROM THE SECOND AND COMPLETELY REVISED EDITION, WITI THE SPECIAL SAYCTION OF THE AUTHOR,

AND EDITED BY

FREDERIC HENRY GERRISH, A.M., M.D.,

SURGEON TO THE MANE GENEIRAL HOSPTTAL,

PROFESGOR OF MATERIA MEDICA AND THERAPEUTICS IS BOWDOIN COLLLGE, ETC.

PORTLAND:

LORING, SHORT, AND IIARMON.

\section{a} 1881.

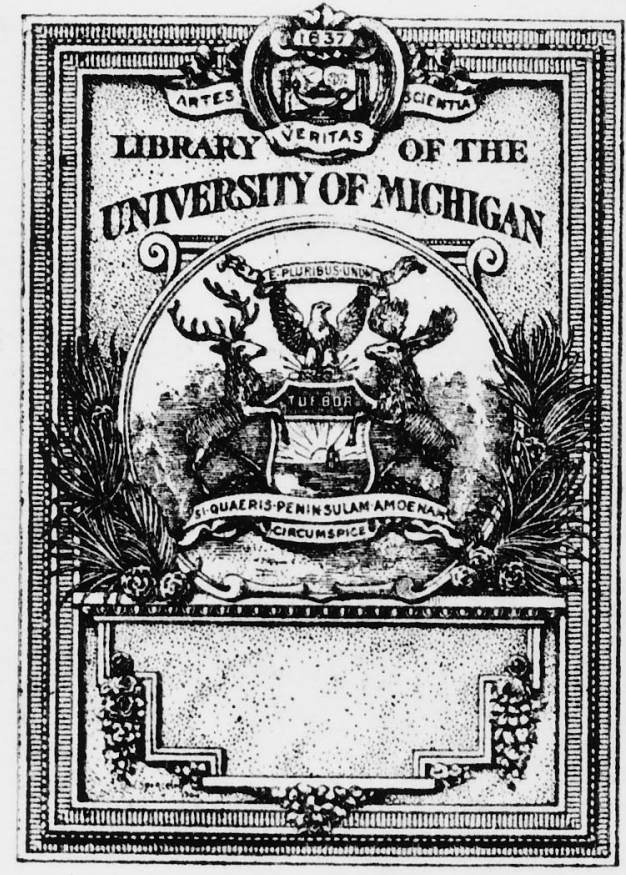

PRESENTED BY

\section{Dr. C. B. G. DEN ANCREDE}

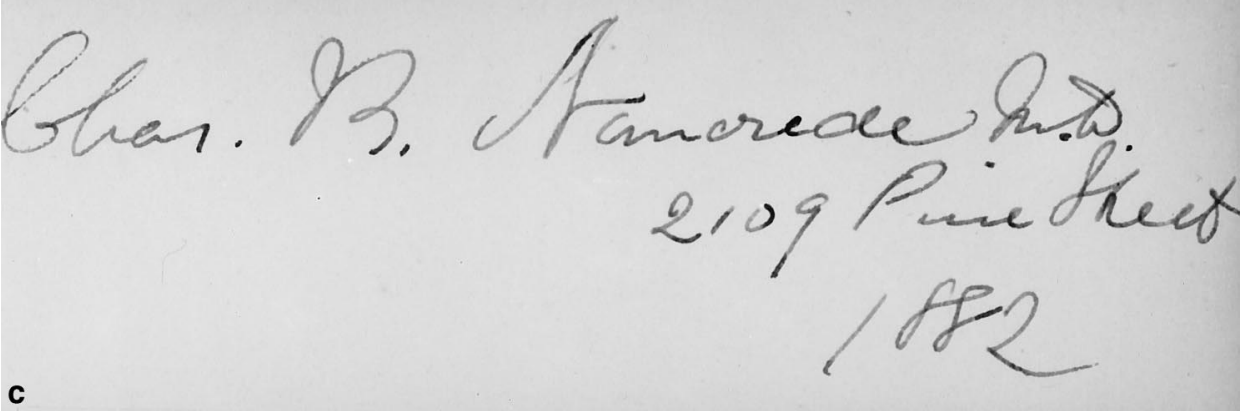

Fig. 2. a. Book donated by de Nancrede to the University of Michigan Medical Library. b. Bookplate. c. Signature of de Nancrede. 

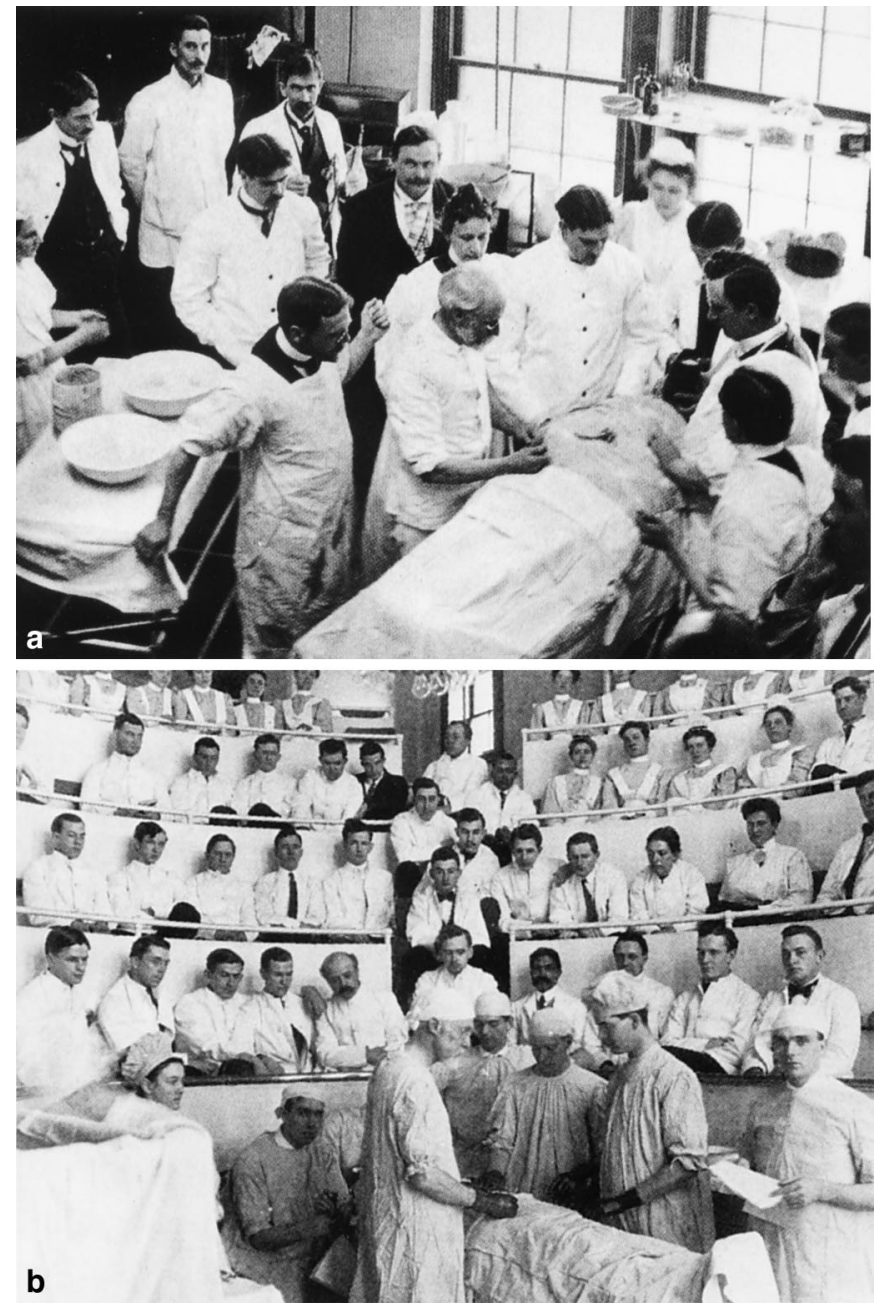

Fig. 3. a. De Nancrede in 1890 in Ann Arbor operating with antiseptic technique but barehanded. b. De Nancrede operating in 1910 used sterile (aseptic) technique and gloves.

first a minor part of the clinical and academic environment. Smith [22] described so well the rise of surgical practice, judgment, and ingenuity.

For the few nontraumatic surgical conditions that existed in 1870 , relatively little surgical judgment was required — pain of sufficient intensity called for lithotomy, blindness from cataracts called for their removal, and so forth. The excitement of "safe" surgery in the 1880s led to scores of new procedures or operations, most of which are no longer practiced. One, because of its phenomenal success became paradigmatic: the management of appendicitis by early appendectomy. Appendicitis and its operative treatment serve as a window on the emergence of surgical therapy as the twentieth century began. In 1890 only a few practitioners saw appendicitis as an exclusively surgical disease to be managed by an experienced surgeon, with an appropriate operation as the most likely therapy.

Certainly, de Nancrede was one of those exceptional surgeons. Medical procedures were just beginning to blossom, as Smith suggested, when the nineteenth century closed. Now, after 100 years we hear surgical procedures branded as noncognitive. The judgment and thought involved in deciding to operate, selecting the operation, tailoring the procedure to the patient, and solving unexpected problems along the way are unquestioned by sur- geons. The noncognitive label is a curious conceit, parochial and unjustified, but oddly in vogue. Since de Nancrede's time a number of interventions have followed false trails and disappeared from our armamentarium, but most that remain improve the human condition. In addition, the human cost of these inventions is decreasing, with less pain and less morbidity due to infection and inflammation. The holy grail of minimally invasive surgery gets closer to our reach as the century turns. Now, at the close of the twentieth century, medical practice is vitally scientific and heavily immersed in procedures. Some observers decry too much science and too many procedures, fearing that we have lost our pastoral roots. If medicine is to cure and comfort, perhaps some practitioners have favored the former over the latter. When that is the case we need to restore balance but not discard advancements in science and surgery.

The contemporary explosion of technology has increased the challenge of surgical judgment and strained the financing aspects of health care. In de Nancrede's time new technology meant tools such as radiography, endoscopy, and improved hand instruments, which were generally affordable to a single practitioner or small group of physicians. One hundred years later the technologies are vastly more complex and more costly. Computed tomography, magnetic resonance imaging, lithotripsy, transplantation, cardiac bypass, and gene therapy can be provided only by large, well financed enterprises. As upscaled technology has increased the price tag of health care, and public challenges have been invited regarding the value added by this technology to medical care. Yet if one compares medical practice at the turn of each century, the incremental value achieved during the past 100 years is incontestable to the simplest observer.

Change is inexorable, and paradigm shifts are once again in progress. Etymology reflects these changes at the present fin de siècle: the term "medicine" is replaced by "health care"; "physician" has become "provider"; the "patient" is now a "consumer"; and the solitary enterprise of "surgical practice" performed by the likes of de Nancrede is now a "commodity" offered by competing networks. Public policy today promotes the generalist over the specialist and the outpatient office and home care over the hospital. In a relative sense, these changes are as monumental for us as those experienced by de Nancrede and his peers. Although the new transitions are daunting, surgeons throughout centuries past have proved themselves a clever lot, and they should be able to rise to these new challenges.

\section{Résumé}

A la fin du siècle dernier, les standards de la chirurgie américaine évoluaient. Ces changements intéressaient la technologie, l'exercice de la chirurgie, la spécialisation, les soins, l'enseignement et l'économie de la chirurgie. Le docteur Charles B.G. de Nancrede occupait une place importante pendant cette période. En effet, il était une figure importante pendant la période de transition des antiseptiques à la chirurgie dite stérile. C'était également un écrivain prolifique, un chirurgien courageux et un enseignant hors paire. Le docteur De Nancrede a été responsablede la création d'un des premiers départements mulit-spécialités modernes. La fin de ce siècle promet de nouvelles transitions comparables à celles du passé. 


\section{Resumen}

A finales del siglo pasado y comienzos del presente, la cirugía norteamericana se hallaba en pleno cambio de paradigmas, a juzgar por transiciones en cuanto a tecnología, práctica, especialización y adiestramiento quirúrgicos y economía médica. Charles B. G. de Nancrede surgió como líder en este período formativo, siendo figura clave en el proceso de transición de la técnica aséptica a la técnica estéril; fue un autor prolífico, un cirujano audaz y un gran educador quirúrgico. De Nancrede creó uno de los primeros prototipos de departamento de multiespecialidades quirúrgicas. El cambio de siglo que se avecina promete nuevas transiciones comparables con aquellas del pasado.

\section{Acknowledgments}

The authors acknowledge the assistance of The Bentley Historical Library of the University of Michigan; the Babcock Urological Endowment Fund at the University of Michigan; Dan Flanagan, Archives Technician at Scott Memorial Library, Jefferson Medical College; and Marvin L. Bloom, M.D.

\section{References}

1. Warthin, A.S., Peterson, R., Lloyd, A.H.: Charles Beylard Guerard deNancrede 1847-1921: a memorial read before the University Senate May 16, 1921. Michigan Alumnus 27:567, 570, 573, 1921

2. Davenport, H.W.: University of Michigan Surgeons 1850-1970: Who They Were and What They Did. Ann Arbor, University of Michigan, 1993, pp. 42-43, 292-293

3. University of Michigan Encyclopedic Survey (vol. II, parts 3, 4, 5), W.B Shaw, editor. Ann Arbor, University of Michigan Press, 1951, pp. 941, 943

4. De Nancrede, C.B.: The effects of modern small-arm projectiles, as shown by the wounded of the Fifth Army Corps, during the campaign resulting in the capture of Santiago de Cuba. Transact. Am. Surg. Assoc. 17:43, 1899

5. De Nancrede, C.B.: The occasional presence of the appendix vermiformis on the left side of the abdomen, without transposition of the viscera explained: illustrated by an operated case. J. Mich. State Med. Soc. 13:39, 1914

6. De Nancrede, C.B.: Questions and Answers on the Essentials of Anatomy for Students of Medicine. Philadelphia, Saunders, 1888

7. The Compact Oxford English Dictionary (2nd ed.) Oxford, Clarendon Press, 1991, p. 887

8. Watson, I.A.: Physicians and Surgeons of America. A Collection of Biographical Stechtches of the Regular Medical Profession. Concord, NH, Republican Press Association, 1896, p. 137

9. Howell, J.D.: Technology in the Hospital: Transforming Patient Care in the Early Twentieth Century. Baltimore, Johns Hopkins University Press, 1995, p. 17

10. De Nancrede, C.B.: Lectures on the Principles of Surgery. Philadelphia, Saunders, 1889 and 1905, pp. 119, 367

11. Vaughan, V.C.: A Doctor's Memories. Indianapolis, Bobbs-Merrill, 1926, pp. 221-222

12. De Nancrede, C.B.: The value of humanistic, particularly classical studies as a preparation for the study of medicine and of engineering, from the point of view of the professions: from the proceedings of the classical conference held at Ann Arbor, Michigan. The School Review: A Journal of Secondary Education, June 1906, p. 394

13. Watson, I.A.: Physicians and Surgeons of America. Concord, NH, Republican Press Association, 1896, p. 137

14. Nancrede, C.B.: Annual address of the orator of the section on surgery: the modern anti-bacillary treatment of tubercular jointdisease. Mich. State Med. Soc. 16:30, 1892

15. Nancrede, C.B., Hutchings, W.H.: Boiling as a method of sterilizing catheters. Med. News (N.Y.) 82:56, 1903

16. Nancrede, C.B., Waldron, F.R., Tenney, C.F.: A preliminary note on the sterilization and absorbability of catgut. J. Mich. State Med. Soc. 4:511, 1905

17. Lucas-Championniere, J.: Antiseptic Surgery: The Principles, Modes of Application, and Results of the Lister Dressing. Portland, Loring, Short, \& Harmon, 1881

18. Gruner, O.C.: A Treatise on the Canon of Medicine of Avicenna. London, Luzac and Co., 1930, p. 513

19. McBurney, C.: The use of rubber gloves in operative surgery. Ann. Surg. 28:108, 1898

20. Martensen, R.L.: Physicianhood in the 1890s. J.A.M.A. 276:1005, 1996

21. Flexner, A.: Medical Education in the United States and Canada Boston, D.B. Updike, Merrymount Press, 1910

22. Smith, D.C.: Appendicitis, appendectomy and the surgeon. Bull. Hist. Med. 70:414, 1996 